Article

\title{
Social Media Marketing in Creative Industries: How to Use Social Media Marketing to Promote Computer Games?
}

\author{
Bartosz Wawrowski and Iwona Otola * \\ Faulty of Management, Czestochowa University of Technology, Dąbrowskiego 69, 42-201 Częstochowa, Poland; \\ bartosz.wawrowski@pcz.pl \\ * Correspondence: iwona.otola@pcz.pl
}

Received: 27 March 2020; Accepted: 28 April 2020; Published: 30 April 2020

check for updates

\begin{abstract}
Currently, almost every business entity has one or more social media accounts. This statement is true for companies operating in creative areas as well. Social media make it possible to perform widely understood marketing-oriented undertakings. They allow for toll-free presentation of a particular company, its history, products, achievements, as well as for encouraging prospective customers to visit its websites. Social media marketing plays an important role in the satisfactory advertising of creative brands, companies, and products. The aim of this article is to discuss the possibilities of utilizing social media marketing by a creative company dealing with the production of computer games. The authors have attempted to analyze selected elements of computer game promotion opted for by the CD Projekt Capital Group. As of currently, The Witcher game is a product that is well known and highly appreciated all over the world. Nevertheless, its promotion has required the utilization of a proper marketing strategy, based on social media-specific tools.
\end{abstract}

Keywords: computer games; creative companies; social media marketing

\section{Introduction}

Up until recently, the "creative sector" term has been rarely used. Its importance for companies has increased as a result of notable changes of business specificity. When it comes to the widely understood creative industry, growth factors have been, inter alia, the emergence of the $B+R$ sector, human capital intellectual changes, as well as, the increase in demand for the offered products. In order to properly define the "creative sector" notion, one has to start from touching upon the very "creativity" term. It is defined differently by various fields of science. When it comes to economy, it is predominantly oriented towards innovative solutions achieved thanks to the development of science, investments, and proper human resource management. In art, creativity is perceived as the ability of creating something original and new by taking advantage of fresh ideas and imagination. Creativity can therefore be considered to be the ability of creating and developing new concepts, solutions, ideas, and tools [1].

For the very first time, the creative industries notion emerged in Great Britain at the end of the 90s. In the Creative Industries Mapping Document report, the creative sector was defined as the one pertaining to branches that show the capability of creating workplaces and wealth, as a result of individual skills, creativity, and talent [2]. Thirteen sectors in which creativity had been promoted were indicated in the document. The proposed selection included, among others: designing, programming and computer services, architecture, advertising, TV and radio, publishing sector, and interactive entertainment-oriented software creation. Creative sectors have been providing products and services that are typically connected with artistic, cultural, or entertainment-specific values. The modern economy is, to a remarkable extent, based on the use of creative energy, imagination, and knowledge, 
to develop unusual ideas, initiatives, and values. To a notable extent, both the expansion and market success of an organization are dependent on taking advantage of not only technological innovations and entrepreneurship, but of creativity as well [3].

A rather different understanding of the creative sector was proposed by the UNCTAD (United Nations Conference on Trade and Development). According to the established definition, it should be understood as recurring cycles of creation, production, and distribution of goods, in case of which the major resources opted for are creativity and intellectual capital. Said cycles incorporate undertakings based on knowledge. They are typically oriented towards art and generating revenue thanks to commerce and intellectual property rights [4].

According to the World Intellectual Property Organization, the creative sector incorporates all branches, the undertakings of which are aimed towards the creation, production, making, presenting, showcasing, distributing, broadcasting, and selling goods that are protected by copyrights [1].

Companies operating in the creative sector focus on intense commercial competition that covers consumer products, such as fashion and design, digital communication, entertainment, and architecture [5]. Said sector consists of national institutions, private companies, and non-profit organizations. The goal of such institutions, firms, and organizations is not only to communicate with the society, but also to create new meanings. It has been highlighted that it is a mistake to perceive the section in question exclusively through the prism of culture. It has to be remembered that marketing and advertising agencies are also included in the creative sector, even though they are connected with culture to a lesser extent than publishing houses and film agencies are [6].

Based on the presented examples of creative sector definitions, it is possible to draw a conclusion that it has a remarkable impact on the development of entrepreneurship and the overall economy of a given country. In the competitive economy, creativity is of increasing importance. Product price and the method of its production have become remarkably less vital. Creativity is an indispensable element of innovativeness and that is why the policies of numerous companies are oriented towards promoting creative patterns of behavior in employees. Up until recently, competing companies have been predominantly focused on limiting production costs and lowering the price of offered goods. Some of them have been looking for cheaper laborers in the Far East and have been opting for cheaper materials. Nevertheless, a notably better solution has turned out to be to support the creativity of workers in their attempt to improve technology and increase product quality. Therefore, it can be said that ideas, skills, and openness to new solutions or concepts are all of immense importance.

Companies from the creative sector have been focusing on creating value by means of utilizing social media. Such media have been used as distribution channels for the offered products and services, as well as utilized as vital marketing tools. Creative companies are exceptionally skilled when it comes to the utilization of social media and taking advantage of them in the managed business undertakings [7].

According to the opinion of experts, Polish creative companies have been achieving best results with regards to the creation of non-material and digital products. To prove that point, one may indicate the creation of games, comic books, and music. Polish creators have been awarded with various prizes for their outstanding animations, music, or even films. Domestic designers and stylists have also been appreciated all over the world. Social media marketing has proved to play an important role in presenting both the brand itself and products provided by creative companies.

The meaning of the creative companies and the role of social media marketing in it should be pointed out. There is relatively little researches on this subject or at least we have not come across them. Social media as a marketing technique is discussed in the context of different sectors or branches. Our article sheds light on a new direction of research in the field of the creative sector. Social media is used widely, for example in managing the IT companies [8], or in luxury item marketing [9]. This is crucial, as the computer games market is increasing from year to year. According to Newzoo [10], in 2019, this market reached the value of 148 billion USD. In addition, the Z-generation, to which the offer of companies specializing in computer games is largely addressed, has a natural connection to 
the digital world. For the $\mathrm{Z}$ generation, the most useful means of communication is by social media which uses the modern technologies. Because of this knowledge, we would like to check whether the theoretical description of social media as a modern marketing tool is used by computer games companies, and if so, to what extent. The predominant aim of this article is to discuss the possibilities of utilizing social media marketing by a creative company dealing with the production of computer games. The authors have attempted to analyze selected elements of computer game promotion opted for by the CD Projekt Capital Group.

\section{Literature Review}

The concept of social media and social media marketing.

Nowadays, a key field of e-marketing undertakings is so-called social media marketing. It is caused by an increasingly more important role played by social media worldwide. Before attempting to define social media marketing, the authors are going to touch upon the very notion of social media and their specificity. The "social media" term is strictly connected with two research fields, namely-communication sciences and sociology. In the communication-specific context, media are the means of storing or sharing either information or data. When it comes to sociology, social networks are societal structures consisting of a set of social entities (individuals, groups, and organizations), and a set of connections between them. Social media are characterized by direct and multidirectional information exchange, speed, and dynamic nature [11]. The topic of social media has been approached similarly by Dutot and Bergeron [12], as well as by Kim and Ko [13], who have considered them to be a set of online tools allowing to publically share ideas with others, create and edit the content, as well as to establish relations by means of interaction and cooperation.

Together with the popularization of the Internet, social media have become a key online marketing tool. Not only individual users, but also companies, have created fan pages on digital platforms and developed business opportunities via social media [14]. The literature of the subject clearly states that the notion in question is, to a notable extent, connected with sociology and communication sciences [15]. Social media marketing is defined as commercial marketing events or processes taking advantage of social media platforms in order to positively affect purchase-related patterns of consumers [16]. Social media marketing is perceived similarly by B. Schivinski, who considers it to be a phenomenon strictly connected with gaining attention and generating online traffic via social media. The discussed tool has become increasingly more important in terms of marketing undertakings organized by various companies, because social media can be easily accessed by a vast group of potential recipients. Social media marketing minimizes the cost of marketing undertakings, as well as allowing one to reach a highly specific target group [17]. The interaction of customer behavior allows users to create identical ideologies pertaining to a given community and strengthen bonds between its members, therefore consolidating the aforementioned community. Said process can be also interpreted as overlapping user values and values followed by the community [18].

To perform marketing undertakings, various platforms are taken advantage of, such as Twitter, Facebook, YouTube, LinkedIn, and numerous blogs. The presence of a number of platforms in the digital environment results in the increase of user traffic. At the same time, there is a constant competition to acquire and retain the message recipient. Currently, undertakings performed by various companies are not only oriented towards acquiring Internet users, but also encouraging them to disclose some pieces of information pertaining to themselves, their fields of interest, and preferences. The gathered data are then taken advantage of to generate further profit. By understanding the needs of consumers better, it is possible to create a tailor-made product for them. Thanks to the Internet, consumers are capable of gathering information about products and sharing their knowledge and experiences with other clients. Social media make it possible for consumers to have a notable impact on widely understood consumption [18].

In many companies, especially those operating in the creative sector, the concept of social media is of paramount importance when it comes to marketing actions. Their owners and managers do their 
best to exploit such applications as YouTube, Facebook, Twitter, or Second Life to the greatest extent possible [11].

The goals of social media marketing are predominantly connected with increasing brand awareness among users, advertising products, and improving customer servicing quality, as well as maintaining consumer loyalty at a satisfactory level. Social media marketing minimizes the costs connected with customer acquisition and allows for gathering the contact data of prospective purchasers, including e-mail addresses or phone numbers. An auxiliary goal of undertakings performed is to encourage Internet users to share obtained pieces of information with their friends, which results in the increased reliability of the published content. Application designing can be supported by the use of highly compatible materials and making such content available for mobile users [19].

Social media marketing can therefore support traditional marketing actions of various companies and organizations, while at the same time allowing their representatives to use a number of tools based on communication channels. The most commonly used social media marketing tools are: blogs, microblogging (e.g., Twitter), co-creation (e.g., NIKEiD), social bookmarking (e.g., StumbleUpon, forums and discussion boards (e.g., Google Groups), product reviews (e.g., Amazon), as well as video and photo sharing (e.g., Flickr, YouTube) $[11,15,20]$.

Other tools that have to be pointed out and that have a remarkable impact on social media marketing as such are:

- Company's website: such website can be considered to be a visiting card of a company, for it incorporates basic data pertaining to it, applications, and links to external data. Many firms and organizations utilize websites for marketing purposes [21].

- E-mail: interactive form of direct marketing, promotional message, or informational content. In such a case, the utilized communication tool is digital messaging. E-mail marketing covers analyzing, planning, realization, and exercising control over the most important processes, namely: creation, expansion, and management of the database of e-mail addresses of users, preparation of content and graphic elements of e-mails, sending messages, and managing replies. An important element of e-mail marketing is the creation of communication schemes in order to personalize and optimally adjust e-mail messages to particular groups of recipients [22].

- Fan page: profile created on a specific social media portal and used to communicate with buyers (or brand/company fans), as well as to allow consumers to share knowledge with each other [23].

- Mobile application in two versions. The first one pertains to the promotion of application installation. Its goal is to increase the number of applications. Thanks to the fact that the users provide information on their interests and preferences, it is possible to organize customized marketing campaigns. The second version is addressed to individuals who have already installed the application. The performed undertakings aim to increase their engagement [24].

- Company's blog: a place to publish valuable posts that can be commented on and tagged by the recipients. A blog is a perfect place to present values that a given company or brand follows to a wider audience. A properly managed blog is not only the source of information about the brand, but also allows to dispel any doubts some consumers may have and encourage them to purchase a product or a service. Blogs can also inform about possible problems that clients may have, while taking advantage of goods provided by a particular company [25].

- Marketing-oriented games: they are created to promote specific products or brands. Gamers are a large, diversified, and attractive part of the global advertising market. Advertising via computer games is a relatively new form of marketing-specific communication [26].

- Content marketing: acquiring clients by means of valuable content published in communication channels supervised by the company; typically utilized marketing forms in this case are newsletters, video materials, graphic reports, company's blogs, topical websites, virtual conferences, and podcasts. Said method is not only about publishing content, but also about listening to client's needs and fully understanding them [27]. 
- Viral marketing: arranging a situation stimulating users to share information with each other on their own. Viral marketing is a variation on word-of-mouth marketing [28]. Viral marketing is also described as a set of advertising-specific tools that are addressed to certain groups of recipients and are utilized in such a way as to encourage them to share a specific piece of information in order to increase the awareness (of a brand, product, or service), or to increase sales [29].

The tools presented above are utilized by companies to acquire clients, engage them emotionally, curate positive experience, and increase the willingness to communicate. They allow to aggregate data on clients and to identify their needs.

\section{Advantages of Social Media Marketing in Creative Industries}

Social media represent great opportunities for the development of the creative branch. By taking advantage of message boards, companies characterized by creative focus can showcase their skills, proposals, ideas, and assumptions to a remarkably large audience. Such an approach allows one to not only gain some popularity and to become more recognizable, but also to establish contacts with other firms, including those creative ones, and conclude lucrative contracts. The creative sector utilizes various social websites for marketing purposes, making them the driving force of the market. It goes without saying that products that are specific for this branch of industry require the utilization of modern marketing forms [30].

Products offered by the creative sector have certain specific features determining their innovativeness. There is a risk of improperly adjusting the goods to the needs of customers or the current trends (e.g., in the case of fashion). It may happen that products supplied by the creative sector face market barriers or limitations. Therefore, marketing-oriented support turns out to be of vital importance. One of the key motivators is to develop an efficient marketing campaign based on the use of social media. It has to be noted that said undertakings also have to be creative in character for the advertised product (brand, company) to stand out from the crowd of other ones. The campaign has to show that the offered item or service is original and innovative [31].

By opting for social media to achieve their goals, companies have to take into account aspects distinguishing them from other online media, especially connections between and the organization of social media network. Elements of social media are based on theories of many fields of science, including psychology, marketing, and sociology. While preparing a campaign, one has to specify: content, motif, societal roles, interactions, and network structure, which may turn out to be of immense help while designing and developing a multimedia project [32].

One may also wonder why social media marketing is so useful for companies operating in the creative branch of industry. Above all else, it allows for almost instant communication with clients. Companies receive feedback on the offered products, as well as some negative pieces of information or suggestions. Every content published in social media results in a reaction. The more creative the content and the esthetical elements utilized, the greater the traffic generated by a specific website. Thanks to this, a firm or a brand becomes much more distinguishable. Alluring images, useful pieces of information, and quick responses to questions asked all result in positive experiences on the side of the client and increase his or her loyalty. Creative companies can achieve marketing success if they care about keeping the published pieces information up to date. Data published in social media should attract the attention of their users [33].

Costs associated with marketing actions performed are of importance for every company. Advertising products or services in TV, radio, or cinemas is remarkably expensive. On the other hand, promoting one's goods or services in social media generates reasonable and acceptable costs. It is not only effective, but also a cheap form of advertising products, brands, or companies to the market. What is more, the reach of such a campaign is almost unlimited in character. Said fact is undoubtedly a huge advantage of social media marketing [34].

Yet, another benefit of utilizing social media marketing is the possibility of reaching specific target groups, which is especially important in the case of creative companies, as well as presenting a 
specific content to a remarkably wide audience. For example, adverts can be presented based on the user's location (province, city). One can manage comprehensive campaigns in social media, organize competitions, and offer goods for reasonable, competitive prices.

Analyses of customer behavioral patterns, number of visits, comments, and likes are also vital. Data gathered in such a way can be used to develop a new social media campaign.

\section{Methodology and Specificity of the Examined Entity}

An empirical analysis of the use of social media marketing-specific tools has had the form of a qualitivate research based on case study. The authors would like to illustrate how the examined creative company has been taking advantage of social media marketing tools and which one of them have been key for it with regard to reaching the potential customer. The theoretical assumptions presented above have served as the basis of identification of used tools and the creation of an efficient marketing strategy. To evaluate the social media marketing we used methods of examining documents (mainly reports) and websites. Information about CD Projekt comes from the internal sources of the company [35].

In 2011, after the transformation of the Optimus Company and the acquisition of CDP Investment, the CD PROJEKT Capital Group was established. As of currently, it incorporates the CD PROJEKT RED game development studio and the GOG.com online distribution platform. The major focus of the company is the production and sales of video games. The headquarters of the company is located in Warsaw and its regional branches can be found in Cracow and Wroclaw. Individuals employed in the aforementioned three units are responsible for creating video games. It is also worth mentioning that the company has its offices in Berlin, Los Angeles, Tokyo, and Shanghai-they coordinate marketing and sales undertakings in Asia, the United States and Europe. The greatest achievement of CD Projekt Inc. was the creation of a series of Witcher-themed games based on the works of Andrzej Sapkowski.

The CD PROJEKT RED development studio was established in 2002 and has been dealing with making games for PCs and consoles. Their most recognizable game series is The Witcher.

When it comes to GOG.com (formerly-Good Old Games), it is a digital videogame distribution platform. It has a global reach, which means that it attracts customers from the entire world. Thanks to the GOG Galaxy platform being one of GOG.com website's inventions, the clients have the possibility of playing online. The platform grants all the interested individuals the access to social and online services. The GOG.com website is an independent digital distribution platform offering interested players over 2350 meticulously selected games, made by over 550 producers and published from all over the world.

While producing its games, CD PROJEKT RED utilizes its proprietary software (game engine) entitled REDengine, which allows for the use of state-of-the-art technology while making complex plot-driven videogames. Sales are in $80 \%$ of cases realized via digital distribution platforms, such as: Google Store, GOG.com, AppStore, Origin, Steam, PlayStation Store, and Xbox Games Store.

The games that can be bought are available on the aboved mentioned platforms and in the near future will be introduced to an international platform, PSNow, which as of now, April, 2020, is not yet available in Poland, but gives many possibilities. PS Now is a revolution, which allows one to play many different games form PlayStation console (especially PlayStation 4) without installation - the game streaming from Sony servers is used instead. We do not need to have that particular game [36]. The platform, thanks to its characteristics, is a form of the marketing tool, as it positions chosen contents on the main page and the purchase of the subscription and the ability to stream and play online, which is used with the multiplayer option. Play Station Now also has an official account on Facebook, on which they post information about new games on the platform and allow people to purchase a subscription via Facebook shop. Sony can reach the prospective customers of PS Now and develop the awareness among the players about the platform, via Facebook account. What is more, they also try to discourage a player from buying a traditional $C D$ game or saving games on the 
drive and encourage them to stream the games and showing that they can choose from many different games in return for the small price of the subscription.

In June 2018, during the Electronic Entertainment Expo, CD PROJEKT RED showed the world a trailer of the Cyberpunk 2077 game. The game in question has been awarded with over 100 prizes.

\section{Case Study —Forms of Online Promotion Influencing the Success of Games}

Without a shadow of a doubt, the CD PROJEKT Capital Group can be considered to be a creative enterprise. The realized projects are unusual and highly specific in nature. The popularity of The Witcher games based on the books by Andrzej Sapkowski grants their creators an honorary place among the best videogame makers. The game is available on the Steam platform.

The promotion of the game is going to be discussed on the basis of selected forms of social media marketing, with regards to such fields as: company's goals, platforms adopted to pursue company's goals, target audience, distribution channels, and content shared (see Table 1).

Table 1. Computer game promotion by the creative company-case study.

\begin{tabular}{|c|c|c|c|c|}
\hline Company Goals & $\begin{array}{c}\text { Platforms } \\
\text { Adopted to Pursue } \\
\text { Company's Goal }\end{array}$ & Target Audience & $\begin{array}{l}\text { Distribution } \\
\text { Channels }\end{array}$ & Content Shared \\
\hline Brand awareness & $\begin{array}{l}\text { Social networks } \\
\text { sites }\end{array}$ & $\begin{array}{l}\text { Existing and } \\
\text { potential customers } \\
\text { being passionate } \\
\text { about gaming }\end{array}$ & Games shop & $\begin{array}{l}\text { New product } \\
\text { information }\end{array}$ \\
\hline Lead generation & $\begin{array}{l}\text { Microblogs \& } \\
\text { Videoblogs }\end{array}$ & & Online platforms & $\begin{array}{l}\text { High quality } \\
\text { research material to } \\
\text { potential customers } \\
\text { The goal is to }\end{array}$ \\
\hline Customer loyalty & $\begin{array}{c}\text { Content } \\
\text { communities }\end{array}$ & & & $\begin{array}{l}\text { provide influencers } \\
\text { with support with } \\
\text { regard to the } \\
\text { buying process }\end{array}$ \\
\hline Value of company & $\begin{array}{c}\text { Webcasts } \\
\text { Product review } \\
\text { sites }\end{array}$ & & & \\
\hline
\end{tabular}

Content marketing is one of the ways of reaching the potential customer utilizing social media. Its goal is to present a product or a company in such a way for the very content of the information published to be considered interesting by the recipients. What is more, materials required or frequently searched for by the users can be provided. Materials published within the content-oriented website affect the overall loyalty of the user. The product itself, namely The Witcher game, has been presented in a non-intrusive manner and the creators have opted for numerous content forms, namely:

- product description,

- news,

- review,

- article,

- blog post,

- long-form.

Product description incorporates basic data on producers, publishers, distributors, and software, as well as recommended and optimal hardware requirements. The description also includes game logo and information on other parts of the series. One can also find a short note on the works by A. Sapkowski. The very figure of The Witcher and the historical background are also provided. Yet another important piece of information is the specification of the number of levels and locations. The 
description of the product has been considered to be intriguing by Internet users. The Witcher 3 comes with the following text, encouraging the player to start his or her new adventure:

Travel through the world torn apart by war, fight monsters, and make choices the consequences of which will follow you till the very end of your journey. The Sword of Destiny has two edges. You are one of them.

News should be understood in this context as up-to-date, fresh pieces of information. Such news is, for example, a publication stating that The Witcher game has taken first place in the top 10 games in Poland. Yet another example of news is the information that The Witcher 3 has been the most popular production on the Steam platform. The aim of such a type of content is to provide the user with a short communicate that will interest him or her in the topic.

Game reviews may be published by either users themselves or by experts. Sometimes clients purchase a game after previously familiarizing themselves with the opinions of other people. They trust such reviews. In the case of The Witcher, reviews have been provided by many prominent individuals. What is more, promotional undertakings covered the radio and TV as well. Positive reviews have been published on the website of the game, additionally increasing its attractiveness. Exemplary expert opinions are provided below:

"awesome game with its roots in literature" —The Guardian (British) [37]

"greatest advantages of the game are the variety and the number of location. It is the game for everybody" -IGN.com videogame portal [38]

"one of the best RPG games ever produced" —Gamespot.com [39]

Such reviews make social media users more willing to purchase the game. Many players take different opinions into consideration. It is worth pointing out the management of the measurable aspect of profits. If the opinions on social media were not as important for players, would The Witcher game be as successful and would it have brought as many economic benefits to CD Projekt? The reviews highlight that the whereabouts of The Witcher affect players on an emotional level. All the sequences are directed skillfully, making the production a true masterpiece.

Yet another important promotional tool that has to be mentioned are blog posts. These are honest opinions of people who have played the game:

"The Witcher affected me on a spiritual level, as it has the real \#humantouch. It can be felt that it was made by real people. In the era where graphics and quests are made by algorithms, said fact cannot be underestimated. The Witcher is a real masterpiece to me and its every aspect has a human side to it (... )." [40]

One cannot forget about articles, the authors of which are members of the game development team, as well as IT experts and graphic designers. Articles published in social media have covered such topics as:

"Road to the Witcher 3",

"Why is it worth waiting for the Witcher 3",

"The Witcher 3 first impressions".

The presented forms of advertising point to a remarkable promotion of the game by its users. Various forms of content have a single goal—to win the interest of prospective customers and make them more frequent visitors of the content-oriented website. In order to retain consumers, various quizzes have been published and a number of contests have been organized. Users are informed about news and updates by means of a newsletter. It has to be noted that articles and reviews are frequently "adorned" with photos, charts, and maps. 
A different form of social media promotion used by CD Projekt is targeting, which is based on the optimal selection of clients. Advertising content is published to selected groups of users only. Due to their specific features, they may become the purchasers of the promoted games one day. It has to be stated that thanks to social media, a creative enterprise can additionally gather information on such clients. A selected group of customers is undoubtedly interested, not only in the offered game, but also in the content published on the website. Targeting allows to minimize company's spending on advertising. Thanks to properly planned e-marketing undertakings, sales are maximized in a multidirectional manner. One may distinguish such types of targeting as authorial, behavioral, and contextual [41]. The very first of them is based on selecting a target group showing interest in video games. Behavioral targeting pertains to users selected on the basis on their actions. Based on users' activities on other portals, their customized profile is being developed. Then, a company targets its ads to individuals meeting certain criteria only. When it comes to contextual targeting, it is based on segmenting materials with regard to their topic. Information about a game should be published on videogame-related websites and portals alike.

An intriguing form of promotion chosen for the analysis is so-called client segmentation. It is based on dividing the market into smaller groups of clients, with the focus being put on their age, sex, educational attainment, place of residence, fields of interest, frequency of purchases, etc. During segmenting-related undertakings, the possibility of specifying the size of a particular segment is taken into account. Segments should be of varying size and address demographic factors. An important aspect when it comes to client segmentation is customer accessibility. A company should be able to reach them with its offer (for example, children should be excluded). According to the gathered data, gamers (people who have played an online game within the last month) typically are [42]:

- $\quad \operatorname{men}(57 \%)$,

- $\quad$ individuals aged $15-24(43 \%)$,

- $\quad$ people from big cities (43\%),

- individuals with secondary education- $-44 \%$,

- people with a full-time job- $42 \%$.

It is worth noting that the last version of the game was made in fifteen languages and dubbing was available in seven of them. Game-related marketing cost the company USD 35 million. Aside from the aforementioned forms of promotion, the discussed Capital Group has opted for occasional advertising methods. For example, during Halloween, the game was sold much cheaper. Such sales were organized on Steam and GOG.

The Table 2 contains information on projects conducted by CD Projekt company with social media accounts and the number of followers and subscribers observing them in 2019 and 2020, such as [35]:

- CD Projekt RED,

- The newest game of the company-Cyberpunk 2077,

- Gwint-The Witcher card game, which has many fans around the world,

- The bestseller-The Witcher,

- GOG.com—the platform which distributes digital games. 
Table 2. The number of followers and subscribers.

\begin{tabular}{|c|c|c|c|c|c|c|c|c|c|c|}
\hline & \multicolumn{2}{|c|}{$\begin{array}{l}\text { CD PROJEKT } \\
\text { RED }\end{array}$} & \multicolumn{2}{|c|}{$\begin{array}{c}\text { CYBERPUNK } \\
2077\end{array}$} & \multicolumn{2}{|c|}{ GWINT } & \multicolumn{2}{|c|}{ WIEDŹMIN } & \multicolumn{2}{|c|}{ GOG.COM } \\
\hline & \multicolumn{10}{|c|}{ in thousands } \\
\hline & 2019 & 2020 & 2019 & 2020 & 2019 & 2020 & 2019 & 2020 & 2019 & 2020 \\
\hline Facebook & 296 & 349 & 253 & 416 & 520 & 520 & 1000 & 1500 & 429 & 446 \\
\hline Instagram & 287 & 497 & 0 & 329 & & & & & & \\
\hline Twitter & 426 & 645 & 340 & 704 & 100 & 104 & 1000 & 1200 & 330 & 333 \\
\hline YouTube & 142 & 199 & 431 & 759 & 80 & 88 & 300 & 328 & 49 & 56 \\
\hline LinkedIn & 44 & 77 & & & & & & & & \\
\hline Twitch & 142 & 182 & & & & & & & 55 & 62 \\
\hline bilibili & & 352 & & & & & & & & \\
\hline Reddit & & & 122 & 274 & 72 & 93 & & & & \\
\hline Discord & & & 56 & 129 & & & & & & \\
\hline VK & & & 44 & 79 & 87 & 87 & 84 & 110 & & \\
\hline Weibo & & & & & 56 & 59 & & & & \\
\hline WeChat & & & & & 40 & 56 & & & & \\
\hline Others & 91 & 92 & & & 25 & 54 & & & 25 & 40 \\
\hline
\end{tabular}

From the conducted analysis, we can see that the number of followers and subscribers of social media accounts of CD Projekt company is increasing. It is worth mentioning that during the analyzed period, the company was creating new accounts which became very popular and gained many fans. It is important to point out the number of portals and platforms in social media which are used as marketing tools. We can notice that in every project, the company uses three main platforms-Facebook, YouTube and Twitter, which points out the strong and stabilized position and very strong impact of social media on the prospective customer.

To sum up, it has to be stated that the analyzed creative enterprise utilizes social media marketing to a significant extent. Interesting graphic materials and content encourage prospective customers to purchase the game. What is more, the popularity of the production all over the world makes even the skeptic users of social media to be more willing to give The Witcher a try.

\section{Limitation and Conclusions}

The creative economy makes it possible for entrepreneurs to take advantage of highly advanced technologies and intellectual ways of life. Creative organizations are becoming a dynamic and very profitable sector of the domestic economy. Their major goal is to realize their creative potential; so to synergize human resources, culture, society, and institutional capital. The creative sector is less susceptible to financial and economic crises than its traditional counterpart. In order for the discussed companies to develop, they must take full advantage of social media marketing. Thanks to the communication with the society and clients, they are capable of adjusting their products to the needs of the recipients. The increased focus on creative branches will result in both material and intellectual benefits.

The examinations presented within the scope of this article have certain limitations. The described case study has been executed for a recognizable creative company operating in Poland. It would be worth focusing on other creative enterprises as well, to check whether or not social media marketing trends are similar. In further research, we would like to focus on indicating the relationship between spending on social media and the financial results and value of creative companies.

Our contribution is to show the impact of the social media in creative industry. Mentioning the niche subject of our study and using the qualitative research was aimed at indicating management skills concerning the use of social media as a marketing tool in creative companies. The presented case 
study was aimed at combining theoretical considerations on social media marketing and its practical application in brand identification and promotion. This article could be the source of inspiration for the creative companies and for the people responsible for marketing strategy in this field. From our research, we conclude that social media are the main source of information and a marketing tool, which is developing very quickly, and which is used to consolidate the position on the market and to point the direction in building dominance over the competitors. Currently, social media play an important role in marketing, including in the creative sector. Based on the analysis of promotional undertakings performed by the CD Projekt Capital Group, it has been discovered that it has been actively operating on various fields. The article offers a comprehensive analysis of selected social media-oriented promotion forms. It has been proven that social media marketing can cover various fields that are adjusted to the needs and capabilities of the client. Content published on various websites encourage prospective clients to purchase the advertised game (especially during a sale). Interesting graphical elements, revives, and articles may increase the interest of a purchaser-to-be. Furthermore, pieces of information published on various portals and informing about the overall success of the production make people more willing to give The Witcher a try. Based on empirical examinations, it has been proved that social media marketing-oriented undertakings performed by creative companies are sensible and may yield satisfactory effects. It is important to mention the weak points of the creative sector. Mainly, it is based on the innovative concepts of the individuals. It can be very difficult to maintain a high level of the numbers of followers having such a big number of the competitors. According to the activities of the company, a properly integrated marketing strategy should be used (with the usage of the specific social media platform).

Computer games companies mainly direct their products to the young $\mathrm{Z}$ generation, who do not have the stable source of income. The best way to get to them is through social media. A constant contact with the purchase stimulates opinion exchange and establishing mutual relations. Games produced by CD Projekt are being purchased by clients from all over the world. Positive opinions of the users may encourage prospective clients from all over the globe to purchase the game as well.

Author Contributions: Conceptualization, I.O.; Investigation, B.W.; Resources, B.W. and I.O.; Writing-original draft, B.W. and I.O.; Writing-review \& editing, B.W. and I.O. All authors have read and agreed to the published version of the manuscript.

Funding: This research received no external funding.

Conflicts of Interest: The authors declare no conflict of interest.

\section{References}

1. Mackiewicz, M. Analiza Potrzeb i Rozwoju Przemysłów Kreatywnych; Wyd. ECORYS: Warszawa, Poland, 2009.

2. Department for Culture Media \& Sport. Creative Industries Mapping Document; Department for Culture Media \& Sport: London, UK, 1998.

3. Dronyuka, I.; Moiseienkob, I.; Gregušml, J. Analysis of creative industries activities in European Union countries. Procedia Comput. Sci. 2019, 160, 479-484. [CrossRef]

4. The Creative Economy Report: The Challenge of Assessing the Creative Economy: Towards Informed Policy-Making. United Nations Conference on Trade and Development (UNCTAD): Geneva, Switzerland, 2008.

5. Poettschacher, E. Strategic creativity: How values, beliefs and assumptions drive entrepreneurs in the creative industries. Int. J. Entrep. Innov. 2005, 6, 177-183. [CrossRef]

6. Gryczka, M. W kwestii rozwoju sektora kreatywnego i sposobów jego finansowania. Studia Wydziału Nauk Ekon. Zarzadzania 2015, 41, 213-227.

7. Smith, K.T.; Blazovich, J.L.; Smith, L.M. Social media adoption by corporations: An examination by platform, industry, size, and financial performance. Int. Acad. Mark. Stud. J. 2015, 19, 127-143.

8. Berthon, P. Marketing meets Web 2.0, social media, and creative consumers: Implications for international marketing strategy. Bus. Horiz. 2012, 55, 261-271. [CrossRef] 
9. Godreya, B. Social media marketing efforts of luxury brands: Influence on brand equity and consumer behavior. J. Bus. Res. 2016, 69, 5833-5841.

10. Available online: https://newzoo.com/globalsupport/ (accessed on 22 April 2020).

11. Kaplan, A.M.; Haenlein, M. Users of the world, unite! The challenges and opportunities of social media. Bus. Horiz. 2010, 53, 59-68. [CrossRef]

12. Dutot, V.; Bergeron, F. From strategic orientation to social media orientation. J. Small Bus. Enterp. Dev. 2016, 23, 1165-1190. [CrossRef]

13. Kim, A.J.; Ko, E. Do social media marketing activities enhance customer equity? An empirical study of luxury fashion brand. J. Bus. Res. 2012, 65, 1480-1486. [CrossRef]

14. Shih-Chih, C.; Chieh-Peng, L. Understanding the effect of social media marketing activities: The mediation of social identification, perceived value, and satisfaction. Technol. Forecast. Soc. Chang. 2019, 140, $22-32$.

15. Paliszkiewicz, J.; Koohang, A. Social Media and Trust: A Multinational Study of University Students; Informing Science Press: Santa Rosa, CA, USA, 2016.

16. Dann, S. Redefining social marketing with contemporary commercial marketing definitions. J. Bus. Res. 2010, 63, 147-153. [CrossRef]

17. Schivinski, B.; Christodoulides, G.; Dabrowski, D. Measuring consumers' engagement with brand-related social-media content. J. Advert. Res. 2016, 1, 64-80. [CrossRef]

18. Henning-Thurau, T.; Gwinner, K.; Walsh, G. Electronic word-of-mouth via consumer-opinion platforms: What motivates consumers to articulate themselves on the internet. J. Interact. Mark. 2004, 18, 38-52. [CrossRef]

19. Seyyedamiri, N.; Tajrobehkar, L. Social content marketing, social media and product development process effectiveness in high-tech companies. Int. J. Emerg. Mark. 2019. [CrossRef]

20. Hoffman, D.L.; Fodor, M. Can you measure the ROI of your social media marketing? Mit Sloan Manag. Rev. 2010, 52, 41-49.

21. Peters, K.; Chen, Y.; Kaplan, A.M.; Ognibeni, B.; Pauwels, K. Social Media Metrics—A Framework and Guidelines for Managing Social Media. J. Interact. Mark. 2013, 27, 281-298. [CrossRef]

22. Ellis-Chadwick, F.; Doherty, N.F. Web advertising: The role of email marketing. J. Bus. Res. 2012, 65, 843-848. [CrossRef]

23. Pavlov, O.V.; Melville, N.; Plice, R.K. Toward a sustainable e-mail marketing infrastructure. J. Bus. Res. 2008, 61, 1191-1199. [CrossRef]

24. Chuck, M. The Third Screen: Marketing to Your Customers in a World Gone Mobile; Nicholas Brealey Publishing: London, UK, 2011.

25. Farquhar, J.; Rowley, J. Relationships and online consumer communities. Bus. Process. Manag. J. 2006, 12, 162-177. [CrossRef]

26. Nelson, M.R.; Keum, H.; Yaros, R.A. Advertainment or adcreep game players' attitudes toward advertising and product placements in computer games. J. Interact. Advert. 2004, 5, 3-21. [CrossRef]

27. Lieb, R. Content Marketing: Think Like a Publisher-How to Use Content to Market Online and in Social Media; Que Publishing: Hoboken, NJ, USA, 2012.

28. Kieżel, M.; Wiechoczek, J. Narzędzia e-marketingu w procesie kreowania wartości dla klienta. Zesz. Nauk. Politech. Ślaskiej Ser. Organ. Zarządzanie 2017, 114, 203-220.

29. Touba, O.; Stephen, A.; Freud, A. Viral marketing: A large-scal field experiment. Econ. Manag. Financ. Mark. 2011, 6, 43-65. [CrossRef]

30. Chen, Y.; Fay, S.; Wang, Q. The role of marketing in social media: How online consumer reviews evolve. J. Interact. Mark. 2011, 25, 85-94. [CrossRef]

31. Czaplewski, M. E-Biznes Jako Kierunek Doskonalenia Ustug Ubezpieczeń Gospodarczych; Polskie Towarzystwo Ekonomiczne: Szczecin, Poland, 2007.

32. Mäntymäki, M.; Riemer, K. Enterprise social networking: A knowledge management perspective. Int. J. Inf. Manag. 2016, 36, 1042-1052. [CrossRef]

33. Napoli, P.M. Social media and the public interest: Governance of news platforms in the realm of individual and algorithmic gatekeepers. Telecommun. Policy 2015, 39, 751-760. [CrossRef]

34. Udayangi Wanniarachchi, V.; Mathrani, A.; Susnjak, T.; Scogings, C. A systematic literature review: What is the current stance towards weight stigmatization in social media platforms? Int. J. Hum. Comput. Stud. 2020, 135, 102-371. [CrossRef] 
35. Available online: https://www.cdprojekt.com/pl/ (accessed on 19 April 2020).

36. Available online: https://www.eurogamer.pl/articles/2020-02-06-playstation-now-ps-now-kiedy-w-polscecena-gry-z-ps4-na-pc) (accessed on 19 April 2020).

37. Available online: https://www.theguardian.com/technology/2015/may/13/witcher-3-wild-hunt-review-xboxps4-pc (accessed on 5 January 2020).

38. Available online: https://www.ign.com/articles/2016/08/31/the-witcher-3-review-roundup (accessed on 6 January 2020).

39. Available online: https://www.gamespot.com/reviews/the-witcher-3-wild-hunt-review/1900-6416135/ (accessed on 5 January 2020).

40. Available online: http://zagraceni.pl/wiedzmin10 (accessed on 3 January 2020).

41. Mou, Y. Presenting professorship on social media: From content, strategy to evaluation. Chin. J. Commun. 2014, 7, 389-408. [CrossRef]

42. Krok, E. Rynek gier wideo i jego uczestnicy. Studia Inform. Pomerania 2016, 2, 47-60.

(C) 2020 by the authors. Licensee MDPI, Basel, Switzerland. This article is an open access article distributed under the terms and conditions of the Creative Commons Attribution (CC BY) license (http://creativecommons.org/licenses/by/4.0/). 